University of Nebraska - Lincoln

DigitalCommons@University of Nebraska - Lincoln

September 2007

\title{
Accounting for "Racism": Responses to Political Predicaments in Two States
}

\author{
Byron D. Orey \\ borey2@unl.edu \\ L. Marvin Overby \\ University of Missouri-Columbia \\ Barbara J. Walkosz \\ University of Colorado-Denver \\ Kimberly R. Walker \\ University of Mississippi and Alcorn State University
}

Follow this and additional works at: https://digitalcommons.unl.edu/poliscifacpub

Part of the Political Science Commons

Orey, Byron D.; Overby, L. Marvin ; Walkosz, Barbara J.; and Walker, Kimberly R., "Accounting for "Racism": Responses to Political Predicaments in Two States" (2007). Faculty Publications: Political Science. 21. https://digitalcommons.unl.edu/poliscifacpub/21

This Article is brought to you for free and open access by the Political Science, Department of at DigitalCommons@University of Nebraska - Lincoln. It has been accepted for inclusion in Faculty Publications: Political Science by an authorized administrator of DigitalCommons@University of Nebraska - Lincoln. 


\title{
Accounting for "Racism": Responses to Political Predicaments in Two States
}

\author{
Byron D'Andra Orey, University of Nebraska, Lincoln \\ L. Marvin Overby, University of Missouri-Columbia \\ with: \\ Barbara J. Walkosz, University of Colorado-Denver \\ Kimberly R. Walker, University of Mississippi and \\ Alcorn State University
}

\begin{abstract}
How do people explain their behavior in socially unacceptable political situations? Exploring this question will give us insight into how the public responds to and frames collective decisions regarding controversial topics. We analyze accounts of the outcomes of racially sensitive statewide referenda in two states to understand the public responses to such political predicaments. Distinguishing four broad categories of these accounts - denials, justifications, excuses, and confessions - we find some clear-cut differences in their use between proponents and opponents of the ballot measures. These results have implications for political thought and dialogue regarding politically-sensitive issues and other heated policy issues. We also discuss how the different account dynamics in these two cases presaged subsequent political developments in these states, which might provide insights into why some such cases continue to be fiercely contested while others fade from public debate.
\end{abstract}

PEOPLE IN SITUATIONS that others consider "strange, crazy, untoward, immoral, or inexplicable" (Tedeschi and Norman 1985, 297) will try to extricate themselves by formulating exculpatory verbal accounts. ${ }^{1}$ Politics is an unusually fertile domain of human activity for such accounts since so much of what goes on in politics involves avoiding blame, minimizing problems, denying that anything has gone wrong, or in the last resort, confessing that "mistakes" or "poor decisions" were made in the hope of forgiveness. Recent examples would include President Clinton's repeated-and increasingly legalistic_-denials that he "did not have sexual relations with that woman, Miss Lewinsky"; and President Reagan's use of the "past exonerative" to discuss the Iran-Contra scandal, acknowledging that "mistakes were made" while avoid-

State Politics and Policy Quarterly, Vol. 7, No. 3 (Fall 2007): pp. 235-255 
ing taking any responsibility or detailing the nature of the missteps. But what do we really know about such incidents? Do they have important implications for our understanding of political behavior, policy outcomes, or democratic theory and practice?

Considerable research has been conducted on how people respond to various types of political accounts (Chanley et al. 1994; Gonzales et al. 1995; McGraw 1990, 1991; Riordan, Marlin, and Kellogg 1983), usually with experiments designed to evoke reactions to stylized accounts offered by simulated politicians enmeshed in hypothetical scandals. However, little is known about the circumstances under which those involved in political predicaments actually produce such accounts. This situation has prompted calls-largely unheeded-for analyses of the ways that both participants and onlookers account for real political predicaments (e.g., McGraw 1990, 129; Fenno 1978,162 , who speaks of the need for "theories that explain explaining"). To be sure, typologies of political accounts are available (Bennett 1980; Weaver 1986), as are analyses of account strategies in non-political contexts (Felson and Ribner 1981; Rosenquist 1932). Reasons why so few studies of this important political phenomenon have been conducted are that such predicaments usually arise suddenly and unexpectedly and therefore do not lend themselves to standard modes of social science research, such as opinion surveys, and the psychological processes at work are difficult to simulate validly in the laboratory.

The limited work that has been done in this area has focused on how journalists interpret election outcomes and other political events (Hershey 1992; Kingdon 1966). The production of political accounts seems to peak in two situations: immediately after an election, when candidates and others vie to put their own interpretation on the outcome (Hershey 1992; Thomas and Baas 1996) $)^{2}$, and during a scandal, when the alleged wrong-doers and their accusers swap accusations and denials. Given this tendency, election outcomes that are somehow deemed scandalous or shameful are especially likely to produce frenzies of account-giving and, therefore, be fruitful venues for the study of this phenomenon.

We examine account-giving by taking advantage of such a situation in two statewide referenda that attracted national attention as evidence of pervasive racism in the states involved: the 1990 rejection by Arizonans of a proposed holiday honoring Dr. Martin Luther King, Jr. and the 2001 rejection by Mississippians of a proposal to replace the Confederate emblem on their state flag with a new design less offensive to African Americans. These events present excellent opportunities to extend our understanding of the social 
construction of reality by allowing us to focus on public accounts of these politically-sensitive outcomes.

Our study supplements and extends initial work in this area by Sigelman and Walkosz (1992), who studied one of our cases (the King holiday vote in Arizona). First, we examine two broadly similar events. Second, unlike Sigelman and Walkosz, who examined only letters to the editor, we analyze a wider range of published reactions to these referendum outcomes, including various types of news stories and editorials, as well as letters to the editor. Together, these additional data enhance the generalizability of our study. Third, and most important, where Sigelman and Walkosz's principal interest was simply to use letters to the editor to "provide an accurate gauge of public thinking on controversial issues" $(1992,945)$, our theoretical concerns are more expansive. Our data provide the leverage needed to develop a theoretical, meaningful typology of these accounts. This typology provides us with insights into the dynamics of public posturing over divisive issues. In particular, our analysis of the accounts helps us explain the oft-noted phenomenon of political opponents on a contentious issue to speak past each other, limiting fruitful dialogue. Our results also provide some insights into how the structure of public dialogue may contribute to the resolution (or non-resolution) of contentious issues.

\section{POST HOC ACCOUNTS OF SENSITIVE PHENOMENON}

An account of any phenomenon is simply an explanation of why that phenomenon occurred as it did. Accounts of phenomena that are potentially embarrassing, unsettling, or controversial cause a predicament for the account-giver. There is a tension between telling the unvarnished truth and modifying, by omission, change, or addition, the truth. This temptation to modify an account can be conscious or even unconscious, since the urge to justify one's actions to others and even to oneself is so powerful.

Winston Churchill's oft-quoted remark, "History will be kind to me for I intend to write it," conveys the idea that people are more likely to be the heroes than the villains of the stories they tell. People have a natural affinity for explanations of past events that cast a favorable light on themselves and those with whom they identify (Heider 1958; Hewstone 1990; Pettigrew 1979). The self-serving bias consists of the tendency to attribute one's successes to one's own efforts while seeing one's failures as stemming from external causes (Kingdon 1966). People are less reluctant to embrace accounts that reflect unfavorably on other people or groups. Therefore, accounts offered 
by different people of the same predicament-causing event may, like eyewitness testimony in a trial or the tales of Roshomon's seven samurai, differ markedly.

Scholars have identified four fundamental types of accounts of predicament-causing events (Schlenker 1980; Schönbach 1990; Lyman and Scott 1968; Snyder and Higgins 1988; Weiner, Figueroa, and Kakihara 1991). "Denial" is a claim that the event did not actually occur or that the account-giver had little or nothing to do with it. A variant of denial involves reframing the event, or one's involvement in it, so as to lessen its perceived negativity; providing an acceptable rationale for why it occurred; or suggesting that it was nothing out of the ordinary. A "justification" is an account that stops short of denying the event or one's involvement in it, minimizes the scope or undesirability of the event, sometimes invoking countervailing normative claims or criteria (Schlenker 1980, 138). Third is providing an "excuse" for the event. An excuse occurs when one refuses to take responsibility for "what is admittedly an offensive act" (Semin and Manstead 1983, 80). The fourth and final account is simply offering an admission or "confession."

These four types of accounts likely constitute a hierarchy in terms of their appeal to those who use them. An account that produces total exculpation (denial) is obviously preferable in a predicament, other factors being equal, to one that can result only in partial exoneration (justification), which in turn is preferable to an account that has little potential to absolve the accused (excuse) or one that might even aggravate the situation (confession). A plausible denial might make a predicament disappear altogether. A good justification will not do this, but it can keep a predicament within manageable bounds. If untoward actions cannot be denied or justified, then an excuse may be a plausible fallback. All else failing, the last alternative may be to admit one's guilt.

Those who find themselves groping for a way out of a predicament do not necessarily, or even consciously, begin at the top of this account hierarchy and work their way downward, step-by-step, until they reach an acceptable explanation for a given audience. Other factors related to the account-giver, the environment, and the relationship between the account-giver and listener likely have an effect on the account that is given. For example, people may offer an account that they believe is true even though they know this account may cause others to think less of them or may not sit well with their audience. Similarly, well-known facts may limit the availability (or at least the plausibility) of these account types in particular cases. However, in terms of the potential for repairing one's image, there does appear to be a clear ordering of the desirability of the four types of accounts. 
Thus, we hypothesize that accounts of predicament-causing events will vary in systematic and predictable ways depending on the predispositions of the account-givers. The implication is straightforward for our two cases. When well-publicized referenda outcomes brought disparagement and charges of racism from commentators in the rest of the country, those Arizonans who had voted for the King holiday and those Mississippians who had voted for a new state flag would have formulated significantly different accounts from those who supported the outcomes. Specifically, we anticipate that referendum proponents are more likely to offer accounts that stress excuses or make collective confessions for the outcome they did not personally support, while referendum opponents are more likely to proffer accounts that deny racism or justify the result on grounds other than racist motivations.

\section{THE TWO POLITICAL PREDICAMENTS}

To test our hypothesis, we have identified two political events that cast states' electorates in national disrepute and that citizens and editorial writers felt a need to explain afterward. These events were referendum results that appeared to expose these states' electorates to aspersions of racism.

On November 6, 1990, Arizona voters rejected two referendum measures that would have established a new state holiday honoring Dr. Martin Luther King, Jr. ("King Day"). Proposition 302, which would have added King Day as a new paid holiday for state employees, failed narrowly by a 49.4 percent to 50.6 percent margin. Proposition 301, which would have replaced Columbus Day with King Day as a paid holiday for state workers, received only 24.7 percent of the vote. There had been no concerted campaign pushing for the passage of Proposition 301, reflecting an accord among pro-holiday forces to concentrate on Proposition 302.

The defeat of the 1990 King Day propositions added a new chapter to the holiday's topsy-turvy history in Arizona. Four years earlier, Governor Bruce Babbitt had proclaimed a paid King Day for state employees, but his successor, Evan Mecham, rescinded the holiday, offending those who revered King's memory (O'Neil 1991). Mecham's action triggered "a firestorm of criticism," highlighted by a march on the State Capitol by an estimated 10,000 protesters and boycotts of the state by numerous entertainers and conventions (McClain 1988, 631). In response, Mecham created an unpaid Sunday King Day, but the legislature, sensitive to widespread criticism of the state and its potential economic repercussions, enacted a paid King Day. Opponents of the holiday then succeeded in referring the issue to the voters. A coalition of civil rights and business interests united behind the theme "Support Civil Rights, Help 
Arizona," to wage a vigorous campaign for Proposition 302; in contrast, the anti-holiday campaign was "virtually invisible" (Sigelman and Walkosz, 1992, 939). ${ }^{4}$

Following the defeat of both propositions, the state was left to "live with the stigma of [their] rejection" (Broder 1990), a point hammered home by expressions of shock and dismay from both inside and outside the state. The Washington Post quoted former Arizona House Speaker Joe Lane as saying that in Arizona "there is still a lot of racism out there, whether people will admit it or not" (Stanton 1990). Governor Rose Mofford, nonplussed when a television interviewer asked her whether Arizona was a racist state, falteringly responded, "Well, I feel now that somewhat it is" (Cohn and Burgess 1990). National civil rights leaders issued statements of outrage. The executive director of Operation PUSH advised Arizona voters to "hold their heads in shame because they refused to accept a message of love from a man of color," while the president of the Southern Christian Leadership Conference likened the "insensitive majority" of Arizonans to members of the Ku Klux Klan and warned that all Arizonans would suffer the consequences of the vote (Murphy 1990). As if to bear out that prophecy, the National Football League announced that because of the "negative and divisive message" of the King Day vote, it was relocating the 1993 Super Bowl that had been planned for Tempe, a Phoenix suburb (Sigelman and Walkosz, 1992, 940). National commentators compared Arizona unfavorably to Mississippi and Alabama, and editorial cartoonists had a field day; Oliphant, for example, sketched a "Welcome to Arizona" highway sign that proclaimed a "Martin Luther King-Free Zone" bilingually_in English and Afrikaans, the language of South African apartheid.

Entrenched and widespread racism in Arizona was by no means the only explanation for the defeats of Propositions 301 and 302. As our study shows, there were many influences on these votes, and it is not certain that racism was even among the most important of them. Nonetheless, racism was the account that gained currency nationally and thereby created a predicament for Arizonans. Whereas it had been possible to dismiss Mecham as an aberration who did not represent popular sentiment on this issue, Arizonans could not deny that the defeat of King Day resulted from the actions of hundreds of thousands of their co-residents of the state. In a survey conducted in late November 1990, 80 percent of Phoenix-area residents said they expected the defeat of the holiday to damage the state; only 17 percent expected Arizona to emerge unscathed (Creno 1990).

For our second case of a political predicament, we considered the aftermath of the April 2001 referendum, when Mississippians voted 65-35, to 
retain their state's 107-year-old flag, which combined elements of the Confederate battle flag and the first official Confederate flag, rejecting a new design that featured stars symbolizing Mississippi's admission to the United States as the twentieth state. This referendum evolved from a lawsuit filed against the state in 1993 by the NAACP, which argued that the flag was a racist symbol. Ultimately, the Mississippi Supreme Court rejected that argument, holding that the flag "does not deprive any citizen of any constitutionally protected right" (Mississippi Supreme Court ruling, No. 94-CA-00615-SCT). In the course of these legal wranglings, the state Supreme Court also ruled that the legislation authorizing the 1894 flag had actually expired in 1906, rendering the legal status of the flag questionable. Seeking to extricate itself from the contretemps, the court handed the matter over to the legislative and executive branches, which also dodged the political hot potato by appointing a commission empowered to design an official state flag. The commission recommended a new flag design, which was then pitted against the old flag in the referendum. ${ }^{5}$

As in Arizona, many state leaders sensed there would be trouble if the vote failed and tried to rally support for the new flag. Governor Ronnie Musgrove portrayed it as a symbol of progress for the state: "We believe that it's time to move forward in Mississippi. Our past is very important but we shouldn't dwell in our past" (Sawyer 2001, 1A). Musgrove's endorsement was seconded by several former governors and other prominent Mississippians. The Mississippi Economic Council, a business group, fearful of the impact on tourism and industrial development, emphasized that "those outside our borders still struggle with conflicting images of our state ... many of them not so positive" (Kanengiser 2001, 12A).

The campaigns for and against this referendum were virtual mirror images of those in Arizona in 1990. Unlike the pro-King Day effort in Arizona, the campaign for the new flag was low-key; despite a hefty war chest (roughly $\$ 750,000$ ), no television ads or "eye-catching billboards" appeared (Mitchell 2001, 1A). In contrast, defenders of the old flag held rallies and made strong appeals for grassroots support. Perhaps as a consequence, most Mississippians did not necessarily believe that a vote against the new flag would reflect negatively on the state. In a statewide survey conducted prior to the vote, 58 percent said that keeping the old flag would have no impact on Mississippi's image, and another 14 percent went even further, saying that a vote for the old flag would have a positive impact on Mississippi's image (Gater 2001).

National reaction to the flag vote proved these optimistic expectations to be inaccurate. National newspapers lambasted the state. Cartoonist Mike Ritter of the Tribune Newspapers drew a redneck spelling "M-I-S-S-I-S-S- 
I-K-K-K-I-P-P-I.” The National Collegiate Athletic Association disqualified the state from hosting national championships in intercollegiate athletics, thereby denying Delta State University the opportunity to host the national swimming championships in its new aquatic center. The NAACP threatened an economic boycott, and members of the historically black fraternity, Alpha Phi Alpha, and the International Association of Black Professional Firefighters decided not to meet in Mississippi. Just as had occurred in Arizona a decade earlier, a dark cloud of perceived racism hung over the state, and Mississippians found themselves having to account for a political event that had made them a target of scorn and ridicule in much of the rest of the country. ${ }^{6}$

\section{CATAlOGUING THE ACCOUNTS}

How did Arizonans and Mississippians account for these referendum outcomes that engendered so much ill will toward their states in the rest of the country? The ideal way to answer this question would be to analyze the states' residents' responses to open-ended questions on the subject. Unfortunately, such data are not available. ${ }^{7}$ As an alternate research strategy, we combed Arizona and Mississippi newspapers for accounts of the outcomes of these referenda. Of course, our reliance on media sources rather than opinion surveys meant that the accounts we located and analyzed are not those of a representative sample of voters or the general public in either state. Rather, they constitute the population-or as close to the population as we were able to find-of the accounts of the outcomes of these referenda that were freely and publicly offered in the print media soon after those elections in these two states. As Hershey $(1992,948)$ puts it, "The best place to find ... explanations for election results is in the media." ${ }^{8}$ As such, our data provide good examples of accounts of a predicament-generating election outcome. They also offer one other signal advantage over survey data, in that they represent accounts developed over an extended period after the referenda, usually in a more thoughtful and reasoned way than snap judgments offered to pollsters in the immediate aftermath of the votes. ${ }^{9}$

To catalogue Arizonans' accounts of the defeat of King Day, we transcribed every passage that advanced an account of the defeat of King Day, from news, sports, and feature stories, columns, editorials, and letters to the editor published in 15 of Arizona's 19 daily newspapers during the month immediately following the referenda (November 7-December 6, 1990). ${ }^{10}$ During that period, newspapers were brimming with such accounts. In all, we collected 479 accounts advanced by 278 different Arizonans. Of 
the account-givers, 57 percent were letter-writers ${ }^{11}$ or other members of the general public, 24 percent were public notables of one sort or another, and the remaining 19 percent were newspaper columnists and editorialists. Based on their comments, we placed 142 of the account-givers (51 percent) as proponents of the King holiday and 79 (28 percent) as opponents. We were unable to categorize the remaining 57 (21percent) with any reasonable certainty. ${ }^{12}$ We classified each account using the system of categories in Table 1 below, subsuming each category within the four-part typology of denials, justifications, excuses, and confessions. ${ }^{13}$

We used the same procedures to catalogue Mississippians' accounts of the outcome of the state flag referendum. For the period from April 18, 2001 to May 17, 2001, we transcribed every account of the outcome published in 10 of the state's 12 daily newspapers with a circulation of 9,000 or more. ${ }^{14}$ In all, we identified 249 accounts offered by 211 sources. Of these accounts, 46 percent appeared in letters to the editor, 23 percent in editorials, and 29 percent in news articles. Of the account-givers, 86 (41 percent) were proponents of the new flag, 95 (45 percent) were opponents, and the remaining 30 (14 percent) were unclassifiable. ${ }^{15}$

\section{RESULTS}

In Arizona, denials took two forms. The first consisted of assertions that most voters had actually supported a King holiday. The key support for this account was the fact that of the two separate King Day propositions that had appeared on the ballot, one fell just short of passage and the other garnered a quarter of the votes. Based on the argument that most voters had voted for one proposition or the other, ${ }^{16}$ these account-givers claimed that the outcome was a consequence of disagreement only over the precise form of the holiday, not of opposition to the holiday, per se. The second type of denial challenged the premise that the defeat of King Day was proof of rampant racism in Arizona. According to these account-givers, such a reading could not be accurate, simply because most Arizonans are not racists. In Mississippi, only the second of these two forms of denial was available to account-givers, given the circumstances of the election. Some did, however, deny the implication that Mississippians are racists; a representative statement was "The vote in Mississippi to retain the 107-year-old state flag ... is being depicted in the news as a racial issue. It isn't" (Johnson 2001, 6A).

Arizonans' justifications of the defeat of King Day took three forms. Some claimed that the outcome stemmed from qualms about Dr. King himself, not from hostility to African Americans in general. ${ }^{17}$ Others portrayed the 
outcome as an expression of Arizonans' commitment to such defensible principles as the need to promote economy in state government. According to this account, opposition to the holiday was based on objections to giving state employees another paid holiday at a time when the state was mired in economic doldrums and when state government was held in ill repute. Because Arizona was the only state where the King holiday had been put to a popular vote, some account-givers also argued that if the same referendum had been conducted in other states, the holiday would have been defeated there also.

In Mississippi, we also found justifications based on defensible goals and principles. In one rendition, the desire to pay homage to the state's storied history, account-givers characterized the outcome as a triumph of "heritage, not hate" and "ancestor worship." 18 In a justification based on other principles, account-givers expounded the populist idea that the outcome was justifiable because it was the end product of a democratic process (Covington 2001, 10A). Justifications through comparison (the "everybody would do it" defense) also cropped up in Mississippi, although as in Arizona, they were rare.

The first excuse our account-givers gave for Arizona's rejection of the King holiday was that it was an inadvertent consequence of confusion caused by a long and cluttered ballot, voter apathy, or various shortcomings of the pro-King holiday campaign. Some Arizonan account-givers also held specific groups of voters responsible, especially retirees and residents of rural areas, who were portrayed as not sharing in what was portrayed as the state's generally progressive racial climate. ${ }^{19}$ Others described the outcome as a product of extenuating circumstances, such as news reports, aired just two days before the referendum, of the threatened Super Bowl loss for Tempe if the King holiday were defeated. Such reports were said to have provoked bitter resentment against "outsiders" and a backlash against "economic blackmail."

Some Mississippi account-givers also engaged in scapegoating. In an ironic twist, many of them actually blamed African Americans for the outcome, because, they said, blacks had failed to turn out to vote for the new flag or had even turned out to vote against it (Mitchell and Sawyer 2001, 1B and 5B). Indeed, there appears to be some objective basis for this factual claim, if not the logic behind its use as an excuse. In one statewide pre-election poll, only one white in five, but a majority of blacks favored the old flag. ${ }^{20}$ While those unfamiliar with Mississippi politics may find this ambivalence among the state's African-American population quite unintuitive, it was often cited as an excuse for the outcome. ${ }^{21}$ Others pinned the blame on the governor, the state legislature, or the flag commission. References to external provocation also figured in the accounts of Mississippians who portrayed the outcome 
as a backlash against the NAACP or the NCAA. Some Mississippians also offered a "you can't beat something with nothing" excuse, claiming that the design of the proposed new flag was unappealing and lacked cultural resonance (Crutcher 2001, 12A).

Confessions (sometimes accusatory, sometimes sorrowful) that racism had indeed come to the fore in the King Day vote constituted the final category of accounts in Arizona. In Mississippi, too, some account-givers offered confessions, acknowledging that Mississippians were actually proud of what they had done or simply admitting that Mississippi was a racist place. Representative of such interpretations was the statement that "This so-called 'person of Mississippi' symbolized in the vote to retain the flag of 1894 is white racism” (Warren 2001, 10A).

\section{Proponents Versus Opponents}

An instrumental issue to consider is the extent to which accounts offered by proponents of the two measures differed from those offered by opponents. In the wake of the two referenda, those who had favored the proposed changes were faced with the task of accounting for outcomes they did not favor and for which they were not personally responsible, but that were widely perceived as evidence of racism in their home states. While it would ill serve their states to carry the stigma of racism, beyond their collective stake in refurbishing their state's image, proponents had relatively free rein, if they were so inclined, to offer accounts that reflected critically on those who had opposed the referendum measure. By contrast, opponents found themselves in the predicament of having to account for unpopular outcomes they personally favored and for which they were collectively responsible. Faced with charges of racism, we suspect their natural responses would be to deny such allegations, to downplay the perceived negativity of the outcome, to situate it within the broader context of other goals and principles, or to shift the responsibility for it to outsiders.

Table 1 summarizes and juxtaposes the accounts offered by proponents and opponents of these racially-sensitive referenda. In Arizona, the overall proportions of proponents and opponents offering a denial was similar, but the logic of their denials differed dramatically. Whereas most King Day proponents who denied that their state was racist contended that a majority had actually supported the holiday in one form or the other, hardly any of its opponents claimed this (26.1 percent versus 2.5 percent). Instead, opponents were much more likely than proponents simply to deny that Arizonans were racists, directly contesting such a view of their state (41.8 percent versus 16.9 percent). By contrast, in Mississippi neither proponents nor opponents made much use of 
denial; just one opponent in five and one proponent in eight explicitly denied that the defeat of the new state flag stemmed from widespread racism.

In Arizona, opponents were four times as likely as proponents (70.9 percent versus 18.3 percent) to venture a justification for the referenda outcomes. A much higher proportion of opponents than proponents (13.9 percent versus 1.4 percent) viewed the negative vote as aimed at King himself rather than at blacks or civil rights. Much more importantly, far more opponents than proponents (55.7 percent versus 12.7 percent) alluded to principled bases for the rejection of the holiday, usually by attributing it to economyminded voters who objected to giving state employees another paid day off. In fact, such justifications were the single most common account offered by King holiday opponents in Arizona. In Mississippi, justifications were only half as common as in Arizona among both opponents and proponents (37.9

Table 1. Proponents' and Opponents' Accounts of the Outcomes of Two Racially Sensitive Referenda

\begin{tabular}{|c|c|c|c|c|}
\hline & \multicolumn{2}{|c|}{ Arizona } & \multicolumn{2}{|c|}{ Mississippi } \\
\hline & Proponents & Opponents & Proponents & Opponents \\
\hline I. Denials_"Not guilty" & 36.6 & 41.8 & 12.8 & 21.1 \\
\hline A. "We didn't do it" & & & & \\
\hline $\begin{array}{l}\text {-Denial that the event occurred } \\
\text { B. "We're not like that" }\end{array}$ & $26.1^{*}$ & 2.5 & 0.0 & 0.0 \\
\hline —Denial that the state is racist & $16.9^{*}$ & 41.8 & 12.8 & 21.1 \\
\hline $\begin{array}{l}\text { II. Justifications_-"What's all the fuss about?" } \\
\text { A. "It's really not so bad" }\end{array}$ & ?" $18.3^{*}$ & 70.9 & $9.3^{*}$ & 37.9 \\
\hline $\begin{array}{l}\text {-Minimization of negativity } \\
\text { B. "We had a good reason for doing it" }\end{array}$ & $1.4^{*}$ & 13.9 & $4.7^{\star}$ & 30.5 \\
\hline —Justification through other goals & $12.7^{\star}$ & 55.7 & 3.5 & 5.3 \\
\hline $\begin{array}{l}\text { C. "Everybody does it"-Justification } \\
\text { through comparison }\end{array}$ & 5.6 & 6.3 & 1.2 & 2.1 \\
\hline III. Excuses_-"It's not our fault" & 43.0 & 34.2 & 41.9 & 48.4 \\
\hline $\begin{array}{l}\text { A. "We didn't know what we } \\
\text { were doing"-Unforeseen circumstances } \\
\text { or unexpectedly poor effort }\end{array}$ & es $10.6^{*}$ & 1.3 & 0.0 & 0.0 \\
\hline B. "We couldn't help it"-Extenuating & & & & \\
\hline circumstances & 39.5 & 32.9 & $58.1^{*}$ & 37.9 \\
\hline $\begin{array}{l}\text { 1. "It's their fault"—Scapegoating } \\
\text { 2. "The devil made us do it" }\end{array}$ & $11.3^{*}$ & 0.0 & 30.2 & 33.7 \\
\hline $\begin{array}{l}\text {-External provocation } \\
\text { 3. "You can't beat something } \\
\text { with nothing"-Absence of a viable }\end{array}$ & 28.2 & 32.9 & $23.3^{*}$ & 4.2 \\
\hline alternative & 0.0 & 0.0 & 4.7 & 0.0 \\
\hline IV. Confessions_-"Guilty as charged" & $34.5^{*}$ & 0.0 & $59.3^{*}$ & 3.2 \\
\hline$N$ & 142 & 79 & 86 & 95 \\
\hline
\end{tabular}

Note: ${ }^{\star} \mathrm{p}<.05$ in a z-test of the within-state difference of proportions between proponents and opponents. 
percent and 9.3 percent, respectively), perhaps because it was more difficult for Mississippians to articulate plausible, socially desirable goals to justify their referendum outcome. Among Mississippians, opponents of the new flag were almost four times more likely than proponents to offer justifications (37.9 percent to 9.3 percent), usually opting for a minimization account. ${ }^{22}$

In both states, excuses depicting the referendum outcome as inadvertent were unusual; indeed, in Mississippi we found none of these. In Arizona, although the raw numbers are relatively small, proponents were almost 10 times more likely than opponents ( 10.6 percent versus 1.3 percent) to excuse the outcome as a mistake. In Arizona, roughly the same proportion of opponents and proponents pointed to extenuating circumstances as an excuse for the outcome. Proponents made greater use of scapegoating particular groups of their fellow citizens than opponents did (11.3 percent versus 0.0 percent). This difference did not hold in Mississippi, where scapegoating was common among both groups (30.2 percent for proponents versus 33.7 percent for opponents), largely because both proponents and opponents were prone to identify low black turnout as one principal cause of the result. We found the mirror image of the scapegoating pattern for references to external provocation. In Arizona, such references were fairly common among both proponents and opponents (28.2 percent and 32.9 percent, respectively), many of whom blamed the outcome on a backlash against economic blackmail and the unwarranted intrusion of outsiders into the state's internal affairs. In Mississippi, external provocation was a less prominent excuse overall, although proponents cited external provocations much more often than opponents did (23.3 percent versus 4.2 percent). As a consequence of this, proponents in Mississippi were more likely than opponents to cite any extenuating circumstances (58.1 percent versus 37.9 percent), a difference not seen in Arizona. Traditional culture in the deep-South has long been seen as reflexively resenting and rejecting outside pressure (Cash 1941), so it is odd that flag opponents were virtually moot on this point, leaving it to flag advocates to offer this as a potential excuse for their referendum results.

The starkest divergence in the accounts of proponents and opponents in both states was in their use of confessions. Whereas the acknowledgment of racism was the single most prevalent type of account offered by Arizonans who favored King Day (34.5 percent), no opponent went on record suggesting such a rationale. Even more strikingly, 59.3 percent of the Mississippians who favored the new state flag blamed racism for its defeat, far outstripping every other type of account offered by proponents. But only 3.2 percent of those who opposed the new flag offered an account based on racism.

In summary, denials and excuses were the mainstay accounts for both 
proponents and opponents in Arizona. But, unlike Arizonans, relatively few Mississippians engaged in denial, but they did offer many excuses, irrespective of whether they were in favor of or against the referendum. In both states, justifications were the province of opponents, and confessions were the province of proponents. Specifically, Arizona proponents were more likely than opponents to portray the rejection of King Day as a product of widespread racism, to deny that most Arizonans had opposed a King holiday, to blame opposition by particular groups of Arizonans, and to allude to unforeseen circumstances or unexpectedly poor effort. Arizona opponents were more likely to deny that Arizonans were racist and to offer accounts of the outcome as the result of acceptable goals, not by racism. In Mississippi, two accounts that were popular among opponents in Arizona-the need for economy in state government (justification through other goals) and economic blackmail (external provocation)—were much less prominent in opponents' accounts, presumably because those particular issues had so little to do with mobilizing opposition in Mississippi. On the other hand, even though Mississippians were no more likely than Arizonans to engage in excuse-making, they did make more extensive use of one type of excuse: scapegoating.

\section{DISCUSSION}

What can we learn from this analysis of Arizonans' and Mississippians' accounts of referendum outcomes in their states, which were viewed in much of the rest of the country as the visible "tips of icebergs" of pervasive racism (Shields 2003)? We think there are lessons here both for our theoretical understanding of how people explain political behavior and our understanding of racial politics in the United States.

One lesson is that even though distinguishing among denials, justifications, excuses, and confessions is a key to understanding how people respond to predicaments, delving no more deeply than this four-part categorization would cause one to miss some dynamics of account-giving, both subtle and not so subtle. Many of the interesting contrasts in account-giving in our cases were within each type of account, not between them. The best example of this is that while proponents of the King holiday in Arizona were 10 times more likely than opponents to engage in one form of denial (the claim that most voters had actually supported the holiday), opponents were two-and-a-half times more likely than proponents to engage in a different form of denial (the claim that Arizonans simply were not racists). Another example involved excuses used in Mississippi. Both opponents and proponents offered many excuses for the outcome, but they differed in content. While both groups 
routinely offered up a scapegoat to account for the vote, only proponents of the new flag pinned part of the blame on outside agitators.

A second lesson is that although denials, justifications, excuses, and confessions may constitute a hierarchy in terms of their a priori appeal to those in predicaments, their actual use is not governed by their a priori appeal alone. If it were, virtually everyone would simply deny all bad things and virtually no one would confess. To be sure, the data in Table 1 suggest that these categories of accounts have a hierarchical appeal based on their ability to protect the account-giver's image. The most telling evidence in this respect is the differential popularity of confessions among proponents and opponents. Confessions provided proponents of King Day and the new state flag with an attractive way out of their predicament after these referenda measures were voted down. They could say, in effect, "This was an act of racism," without portraying themselves as racists, for they had supported the proposal. This account might not be ideal since it would reflect adversely on their home state, but it would at least allow them to deflect personal blame. By contrast, any such account by an opponent would, in today's racial climate, be socially unacceptable; branding oneself and one's allies as racists hardly constitutes a face-saving strategy.

The plausibility of an account is also a factor in determining which account type an account-giver will choose. No matter how appealing an account may be on other grounds, if it flies in the face of common sense or brute empirical reality, it is unlikely to be used since it reduces the credibility of the accountgiver. For example, one such implausible account was the (perhaps facetious) attempt of one Arizonan to hold women responsible for the defeat of the King holiday in order to ensure the cancellation of the Tempe Super Bowl (Hatfield 1990). Most account-givers in our study seem to resist the temptation to offer an account that was apt to be dismissed as far-fetched, even if its acceptance promises exculpation.

Finally, these cases provide considerable evidence that accounts matter. Since practical politics is an iterative game, the accounts offered and accepted today affect the political environment in which future iterations of the political game will be played (Bennett 1980). In her experimental work, McGraw (1991) found that the most effective accounts tended to be ones that claimed mitigating circumstances or those that invoked normative principles to justify behavior. In Arizona, one of the most common accounts offered by supporters of the King holiday was the mitigating denial that the voters did not really reject the proposed holiday, since there was majority support for some sort of King holiday in one form or another. Is it surprising, then, that a mere two years after its loss in 1992, there was enough public sup- 
port to get the King holiday back on the ballot, and that this time, it passed by a substantial 61-39 margin? In contrast, in Mississippi, one of the most common accounts offered by opponents of the new flag was to invoke the normative principle of popular will, defending the outcome as the vox populi. The fact that opponents of the new flag were able to wrap an account of the referendum outcome in the language of popular sovereignty may go far toward explaining why the flag issue has been largely dormant since the 2001 referendum.

\section{ENDNOTES}

We are especially indebted to Lee Sigelman, who served as the lead author on an earlier draft of this manuscript. However, because of other professional obligations, Lee was forced to withdraw from the project. We are grateful for his hard work and guidance; without it, this project would not ever have been possible. We are also especially thankful to Herbert Mitchell and Helena Breland for their early efforts in the data collection phase. Lastly, the lead author is thankful to the late Dan Orey, Jr., for his guidance and inspiration.

1. Terminologies used in the psychological and sociological literature on this subject vary. Some (Bennett 1980) use "account" to refer only to justifications and excuses, while others (Lyman and Scott 1968) use the term more inclusively to refer to any explanation of why an untoward event occurred. Similarly, "excuse" is often used to refer to stories of extenuating circumstances (Tedeschi and Norman 1985), but this term is sometimes stretched to encompass justifications or even denials of involvement (Snyder 1985).

2. An example from presidential politics is instructive: " $[\mathrm{M}]$ any Democratic activists in November, 1988, promoted the view that Michael Dukakis's loss was Dukakis's own fault-his staff was disorganized, he failed to respond to Bush's attacks—because this explanation would imply that the voters had not repudiated the Democratic party or its philosophy, but rather that the party simply needs a more effective candidate in 1992. On the other hand, many Republicans tried to convince others that the problem wasn't Dukakis's shortcomings, but the fact that he was solidly within the Democratic mainstream, which is what the voters really rejected. If this explanation were to dominate, it would suggest that officeholders, if they want to build more public support for the next election, ought to vote for Republican initiatives in the meantime" (Hershey 1992, 946).

3. We very much assume in our analysis that account-givers are at least somewhat on the defensive. Indeed, defensiveness is probably the basis of predicaments that produce interesting political accounts. Such accounts are an attempt to "explain unanticipated or untoward behavior" (Lyman and Scott 1968). In our cases, even strong opponents of the new flag in Mississippi and of creating a King holiday in Arizona were cognizant that their positions were not in the majority in the country as a whole and that they would be wellserved by responses that offered some insight, explanation, or argument that would absolve themselves and their states from charges of racism. 
4. The difference in the efforts behind the pro- and anti-King holiday campaigns is succinctly conveyed by the undisputed claim of an anti-King-Day leader that the proholiday forces spent almost $\$ 1$ million, while the opposition campaign spent only a token $\$ 3,000$ (Flannery 1990a).

5. The design of the proposed flag was similar in many ways to that of the existing flag. The major proposed change was the replacement of the Confederate battle flag image in the upper left quadrant with a blue square containing 19 small white stars (representing the existing states as of 1819 when Mississippi became a state) surrounding one large white star (representing Mississippi). This design was based on the "Bonnie Blue Flag" first flown in 1810.

6. In an analysis of white Mississippians' attitudes on the flag issue, Orey (2004) found that "old-fashioned racism" was the strongest predictor of support for the old flag. Reingold and Wike (1998) came to this conclusion regarding a similar vote in Georgia (see also Clark 1997).

7. Sigelman and Walkosz (1992) report the results of a proprietary survey of Arizonans conducted in the wake of the King holiday vote. As the authors note, however, the data themselves are not available for analysis.

8. We also believe that the best media sources for finding well-developed accounts are newspapers, since they tend to be far better and more extensively archived than television or radio broadcasts or pages on the internet.

9. For example, the Arizona survey used by Sigelman and Walkosz (1992) was completed over a three-day period within a week of the King Day referendum. As those authors note, the publicized accounts that appeared later in the media differed somewhat from the survey results in the immediate aftermath of the referendum. See also Hershey (1992) regarding account "winnowing."

10. We omitted four dailies, because they were unavailable due to their small, confined, local circulation. Together, these account for only six percent of daily newspaper circulation in the state in 1990 .

11. This group of account-givers corresponds very closely with those analyzed by Sigelman and Walkosz (1992).

12. We analyzed these accounts broken down according to whether they had been offered by letter-writers or other members of the general public, public notables, or newspaper columnists or editorialists, but these comparisons did not prove illuminating and are not presented here (they are available upon request from the authors). Our inability to classify these 57 account-givers does not mean that they were neutral on the issue; indeed, we suspect that few of them were neutral. They were unclassified because the accounts they offered simply did not provide sufficient evidence for a definitive classification as proponents or opponents.

13. See Sigelman and Walkosz 1992 (941) for coding techniques and inter-coder reliability measures, which were in excess of 90 percent for our study. As Sigelman and Walkosz found, the categories are not mutually exclusive, since a single account could express sentiments from more than one of our categories. Thus, the percentages reported in Table 1 sum in excess of 100 percent.

14. Two newspapers were unavailable to us due to their small, confined, local circulation. They accounted for only nine percent of daily newspaper circulation in 2001.

15. We performed a check of inter-coder reliability using a random sample of 72 of the 
211 sources ( 29 percent), finding coders to be 88 percent consistent in their handling of the accounts.

16. Leaders of the pro-King holiday campaign explicitly urged supporters to vote for Proposition 302 and against Proposition 301. A post-election poll estimated that 63 percent of the voters had supported either 301 or 302 (Flannery 1990b).

17. It is worth remembering that the Arizona referendum occurred less than a year after the first explosive media reports that archivists working with the Martin Luther King Papers Project had found evidence that sizeable portions of Dr. King's 1955 doctoral dissertation in theology at Boston University had been plagiarized.

18. Proponents of the new flag sometimes openly ridiculed such justifications. Nationally syndicated and Mississippi-born columnist William Raspberry put it this way: "Why, lawdy me, this wasn't about race at all. It was about honoring great grandpa's memory, about standing up for the right of the South to be a special place, about defending the southern way of life" (Raspberry 2001, A15). It is worth noting that we coded Raspberry's account as a confession: "I had dared harbor the (faint) hope that white voters might welcome the chance to catapult the state into modernity.... [But] I suspect race was foremost on the agenda."

19. The following passage from a Phoenix Gazette column is representative: "All those people ... who voted against the Martin Luther King Jr. holiday ... probably started out in suburban Chicago, or maybe Nebraska or South Dakota, where people turn 65, move to Arizona, and vote against everything. They don't like schools, mass transit, toxic waste cleanups, museums, dogs, cats, or little children. So why should they vote in favor of a paid holiday for a civil rights leader?" (Spratt 1990). Retirees and rural area residents were singled out more often than any other group as sources of the King holiday defeat, but there were scattered references to other groups as well.

20. However, there was virtually a one-to-one ratio between the white proportion of a county's voting age population and the percentage of voters in the county who voted to retain the old state flag (Klinkner 2001).

21. For instance, consider the following headlines and statements from the state's largest newspaper, the Clarion Ledger (full citations available on request): "Many blacks were not against the old flag"; "NAACP talk of a boycott is laughable: Low black voter turnout on flag issue says everything;" "Talk of a boycott as a reaction to the state flag vote seems laughable - for whether the NAACP can digest it or not, a significant portion of the blame for the failure of the referendum that sought to change the state flag lies at the feet of black Mississippians who sat the election out and didn't vote"; "Did black residents vote to keep flag?"; "Flag: Many black residents just didn't vote, East Miss. Voters League head says."

22. Given the pre-referendum focus on "heritage, not hate" themes, it is perhaps surprising not to see greater differences among the justifications offered by proponents and opponents of the new flag. In the wake of the vote, many opponents seemed to focus on the plebiscitary nature of the outcome rather than on making justifications. For instance, consider the following headlines and statements from the Clarion Ledger (full citations available on request): "Leave Flag alone, people have voted"; "Get over losing vote for new flag"; "Time to admit the people won"; "In spite of the Clarion Ledger using enough ink to float a battleship vilifying the state flag, the good people of Mississippi resoundingly voted to keep it." Given the appeal of invocations of the normative principle of popular rule (a point to which we will return later), this shift 
may have been quite reasonable. It is also evidence of the "winnowing" of accounts observed by Hershey (1992).

\section{REFERENCES}

Bennett, W. Lance. 1980. "The Paradox of Public Discourse: A Framework for the Analysis of Political Accounts." Journal of Politics 42:792-817.

Broder, David S. 1990. “Arizona Soap Opera," in The Washington Post, 5 May.

Cash, W.J. 1941. The Mind of the South. New York, NY: Knopf.

Chanley, Virginia, John L. Sullivan, Marti Hope Gonzales, and Margaret Bull Kovera. 1994. "Lust and Avarice in Politics: Damage Control by Four Politicians Accused of Wrongdoing (or, Politics as Usual).” American Politics Quarterly 22:297-333.

Clark, John A. 1997. "Explaining Elite Attitudes on the Georgia Flag." American Politics Quarterly 25:482-96.

Cohn, Bob, and Mike Burgess. 1990. "Looks Like Tempe to Keep Fiesta Bowl, in Arizona Republic, 12 November.

Covington, John. "Get Over Losing Vote for New Flag." Clarion Ledger, 2 May, 10A.

Creno, Glen. 1990. "Poll Respondents Say King Day Flap Will Harm Arizona," Phoenix Gazette, 6 December.

Crutcher, Pepper. 2001. “Flag Alternative too 'Generic' for State. Clarion Ledger, 9 May, $12 \mathrm{~A}$.

Felson, Richard B., and Stephen A. Ribner. 1981. "An Attributional Approach to Accounts and Sanctions for Criminal Violence." Social Psychology Quarterly 44:137-42.

Fenno, Richard. 1978. Homestyle. Boston, MA: Little-Brown.

Flannery, Pat. 1990a. "King Day Defeat May Spark compromise," Phoenix Gazette, 7 November.

Flannery, Pat. 1990b. “Older, Rural Voters Beat King Day,” Phoenix Gazette, 14 November.

Gater, Harold. 2001. "Survey Results," Clarion Ledger, 5 February: 7A.

Gonzales, Marti Hope, Margaret Bull Kovera, John L. Sullivan, and Virginia Chanley. 1995. "Private Reactions to Public Transgressions: Predictors of Evaluative Responses to Allegations of Political Misconduct." Personality and Social Psychology Bulletin 21:136-48.

Hatfield, C. Donald. 1990. "King Holiday: The Entire State Will Pay," Tucson Citizen, 9 November.

Heider, Fritz. 1958. The Psychology of Interpersonal Relations. New York, NY: Wiley.

Hershey, Marjorie Randon. 1992. "The Constructed Explanation: Interpreting Election Results in the 1984 Presidential Race." Journal of Politics 54:943-76.

Hewstone, Miles. 1990. "The Ultimate Attribution Error: A Review of the Literature on Intergroup Causal Attribution.” European Journal of Social Psychology 20:311-36.

Johnson, Mike. 2001. “Mississippi Not Racist for Keeping Flag.” Clarion Ledger, 1 May 6 A.

Kanengiser, Andy. 2001. "MEC Supports Vote for New Flag," Clarion Ledger, 6 January, $1 \mathrm{~A}$.

Kingdon, John W. 1966. Candidates for Office: Beliefs and Strategies. New York, NY: Random House. 
Klinkner, Philip A. 2001. "Waving the 'White Flag': Racial Voting Patterns in the 2001 Mississippi Flag Referendum.” PS: Political Science and Politics 34:647.

Litton, Ian, and Jonathan Potter. 1985. "Social Representations in the Ordinary Explanation of a Riot." European Journal of Social Psychology 15:371-88.

Lyman, Stanford M. and Marvin B. Scott. 1968. "Accounts." American Sociological Review 33:46-62.

McClain, Paula D. 1988. “Arizona 'High Noon': The Recall and Impeachment of Evan Mecham.” PS: Political Science and Politics 21:628-38.

McGraw, Kathleen M. 1990. “Avoiding Blame: An Experimental Investigation of Political Excuses and Justifications.” British Journal of Political Science 20:119-31.

McGraw, Kathleen M. 1991. "Managing Blame: An Experimental Test of the Effects of Political Accounts." American Political Science Review 85:1133-57.

Mitchell, Jerry. 2001. "Flag Campaigns Low Key," Clarion Ledger, 8 April, 1A.

Mitchell, Jerry, and Patricia Sawyer. 2001. “Did Black Residents Vote to Keep Flag?” Clarion Ledger, 29 April, 1B and 5B.

Murphy, Michael. 1990. “Arizona Image Takes Pounding Over King Day,” Phoenix Gazette, 8 November.

O’Neil, Michael J. 1991. "King Day Deserves a Better Airing," Arizona Republic, 17 March.

Orey, Byron D’Andra. 2004. “A Research Note on White Racial Attitudes and Support for the Mississippi State Flag." American Politics Research 32:102-16.

Pettigrew, Thomas F. 1979. “The Ultimate Attribution Error: Extending Allport's Cognitive Analysis of Prejudice." Personality and Social Psychology Bulletin 5:461-76.

Raspberry, William. 2001. “Two Cases of Denial,” Washington Post, 23 April, A15.

Reingold, Beth, and Richard S. Wike. 1998. "Confederate Symbols, Southern Identity, and Racial Attitudes: The Case of the Georgia State Flag." Social Science Quarterly 79:568-80.

Riordan, Catherine A., Nancy A. Marlin, and Ronald T. Kellogg. 1983. "The Effectiveness of Accounts Following Transgression.” Social Psychology Quarterly 46:213-9.

Rosenquist, Carl M. 1932. "Differential Responses of Texas Convicts.” American Journal of Sociology 38:10-21.

Sawyer, Patrick. 2001. “Opposing Sides Hope Voter Turnout Strong," Clarion Ledger, 17 April, 1A.

Schlenker, Barry R. 1980. Impression Management: The Self-Concept, Social Identity, and Interpersonal Relations. Monterey, CA: Brooks-Cole.

Schönbach, Peter. 1990. Account Episodes: The Management or Escalation of Conflict. New York, NY: Cambridge University Press.

Semin, Gun, and Anthony S. R. Manstead. 1983. The Accountability of Conduct. London, UK: Academic.

Shields, Thomas J. 2003. “The 'Tip of the Iceberg' in a Southern Suburban County: The Fight for a Martin Luther King, Jr., Holiday.” Journal of Black Studies 33:499-519.

Sigelman, Lee, and Barbara J. Walkosz. 1992. "Letters to the Editor as a Public Opinion Thermometer: The Martin Luther King Holiday Vote in Arizona” Social Science Quarterly 7:938-46.

Snyder, C.R. 1985. “The Excuse: An Amazing Grace?” In The Self and Social Life, ed. Barry R. Schlenker. New York, NY: McGraw-Hill. 
Snyder, C.R., and Raymond L. Higgins. 1988. "Excuses: Their Effective Role in the Negotiation of Reality.” Psychological Bulletin 104:23-35.

Spratt, Tom. 1990. “Arizona Reputation Takes Unfair Drubbing on MLK Vote," Phoenix Gazette, 13 November.

Stanton, Sam. 1990. “America Again Looks at Arizona,” Arizona Republic, 9 November.

Tedeschi, James T., and Nancy Norman. 1985. "Social Power, Self-Presentation, and the Self.” In The Self and Social Life, ed. Barry R. Schlenker. New York, NY: McGraw-Hill.

Thomas, Dan B., and Larry R. Baas. 1996. "The Postelection Campaign: Competing Constructions of the Clinton Victory in 1992.” Journal of Politics 58:309-31.

Warren, Harvey. 2001. "History of 1894 Flag Symbolizes Mockery, Irony of Racism." Clarion Ledger, 27 April, 10A.

Weaver, R. Kent. 1986. “The Politics of Blame Avoidance." Journal of Public Policy 6:371-98.

Weiner, Bernard, Alice Figueroa, and Craig Kakihara. 1991. "The Goals of Excuses and Communication Strategies Related to Causal Perceptions.” Personality and Social Psychology Bulletin 17:4-13. 